\title{
The albatross of juvenile criminal records
}

\author{
NICOLA CARR
}

... a regime which condemned people to suffer, like an albatross which they could never shake off, permanent adverse consequences of ancient wrong-doing notwithstanding completion of the ostensible punishment (if any) and irrespective of its continuing significance. ${ }^{l}$

Ah/ well a-day! what evil looks

Had I from old and young!

Instead of the cross, the Albatross

About my neck was hung.

(The Rime of the Ancient Mariner, Samuel Taylor Coleridge)

\section{INTRODUCTION}

Within the United Kingdom, an increasing emphasis on public protection evident in criminal justice and wider social policy has formed the background for the expansion of a criminal record regime which allows for the disclosure of old criminal records and even non-conviction information. Examples of disclosures on criminal record certificates include information on investigations that did not proceed to prosecution, circumstances where a person has been acquitted of an offence (ie where they are found to be legally innocent), and other background information considered to be relevant. The justification for such an intrusion on a person's private life is that it serves a wider public interest on the basis that disclosure of such information may prevent future harm.

The criminal record schemes in the various jurisdictions of the United Kingdom (England and Wales, Scotland and Northern Ireland) are notable in their breadth and stand in contrast to other European countries where access to criminal records is much more restricted and a greater emphasis is placed on their private nature (Jacobs and Larrauri 2012; Larrauri 2014c; Kurtovic and Rovira 2017). In most European countries, a criminal record is considered to be a private matter and therefore not subject to public disclosure (Jacobs and Larrauri 2012). This principle

\footnotetext{
${ }^{1}$ (Lord Wilson at para. 48) $R$ (on the application of $T$ and another) $v$ Secretary of State for the Home Department and another [2014 UKSC 35]
} 
even extends to sharing of criminal record information amongst agencies within the criminal justice system. Furthermore, where criminal records are disclosed they typically only contain information on convictions. They do not provide information on so-called 'administrative sanctions' such as cautions, nor do they contain information on acquittals or police intelligence indicating that a person was previously investigated for an offence (Larrauri 2014a, 2014b).

A further notable feature of criminal record regimes within the United Kingdom is the failure to adequately differentiate between criminal records acquired as a juvenile and those acquired as an adult. This is despite the fact that part of the rationale for the establishment of separate systems for dealing with juvenile offending is the view that children should be treated in a manner that limits the potentially harmful impacts of contact with the criminal justice system. Thus, from their earliest foundations, youth courts have underscored the importance of confidentiality and sought to limit the identification of children involved in criminal proceedings (Jacobs 2014). That a child's welfare should be the paramount consideration in all proceedings is a fundamental tenet of the United Nations Convention on the Rights of the Child (UNCRC). Rights instruments specifically addressing juvenile justice, emphasise the importance of privacy and therefore limiting the disclosure of criminal records acquired as a juvenile.

Looking specifically at the criminal record regime in England and Wales, this chapter will highlight how records acquired as a juvenile for minor offending have been subject to disclosure many years after the event, even in circumstances where the penalty issued at the time was considered to be 'diversionary' and as such on the understanding that fewer consequences would accrue as a result. ${ }^{2}$ Given the low age of criminal responsibility in England and Wales - age 10 - in comparison to a European average of 14 years (Goldson 2013) and the scope for a wide range of criminal information, including so-called 'diversionary' measures, to be included in a criminal record check, the disclosure of criminal records acquired as a child is particularly problematic. A series of legal challenges in domestic and European Courts have highlighted the difficulties with the current regime and the negative impact it has had on areas of life including education, employment, travel and family

\footnotetext{
${ }^{2}$ This chapter focusses on the regime in England and Wales, although there are similar issues with criminal record regimes in Northern Ireland (Mason 2011) and Scotland (Weaver 2018), where different legal regimes apply.
} 
life. In this chapter, the implications of this regime will be considered in relation to children's rights standards. Furthermore, it will highlight the paradoxical situation whereby greater access to criminal records has in many instances been justified by a stated aim to 'protect the public' and in particular to protect children.

\section{CHILDREN'S RIGHTS AND CRIMINAL RECORDS}

Various children's rights standards recognise the differential status of children in criminal proceedings (Kilkelly 2008; Goldson and Muncie, 2012). In these standards, specific emphasis is placed on the need to safeguard a child's right to a private and family life, and to avoid the negative impacts of stigmatisation resulting from contact with the criminal justice system. To this end, in many countries throughout the world criminal justice proceedings involving children are held in private and only participants with direct involvement in a case are allowed to attend (Council of Europe 2010). This emphasis on privacy also extends to prohibitions on the publication of information that would identify a child involved in criminal proceedings. Specifically in relation to criminal records, the United Nations Standard Minimum Rules for the Administration of Juvenile Justice (The Beijing Rules) (1985), state that:

'Records of juvenile offenders shall be kept strictly confidential and closed to third parties. Access to such records shall be limited to persons directly concerned with the disposition of the case at hand or other duly authorized persons.' (Rule 21.1)

Furthermore, these rules state that records acquired as a juvenile offender should not be used in any subsequent proceedings when a child reaches adulthood (Rule 21.2).

The Committee on the Rights of the Child (CRC), the forum through which State parties' compliance with the United Nations Convention on the Rights of the Child (UNCRC) is periodically reviewed, specify in 'Comment No. 10, Children's Rights in Juvenile Justice' (2007) that records of diversionary measures within the juvenile justice system should not be viewed as 'criminal records' and that States should introduce rules which allow for the automatic removal of juvenile criminal records when a child becomes an adult or allow for the removal of certain limited serious 
offences when specific conditions are met (eg not having committed further offences within two years of the last conviction).

In their submission for the last periodic inspection of the United Kingdom's compliance with the UNCRC, the Children's Commissioners of England, Wales, Scotland and Northern Ireland recommended the introduction of a mechanism to allow for juvenile criminal records to be cleared (allowing for exceptions when it is deemed necessary for public protection), when a child reaches the age of 18 (UK Children's Commissioners 2015) ${ }^{3}$. In their concluding observations the Committee on the Rights of the Child recommended that within the UK jurisdictions the minimum age of criminal responsibility should be raised in accordance with acceptable international standards and that diversionary measures should not appear in criminal records (CRC, 2016).

The main thrust of children's rights standards therefore is to privilege diversionary measures as the most appropriate response to dealing with children in the criminal justice system, to emphasise the importance of privacy for children involved in criminal proceedings and to limit the longer-term impacts of contact with the system by restricting the disclosure of criminal records acquired as a juvenile. The rationale for such approaches is grounded in the view that the labeling and stigmatization inherent in the mark of a criminal record impacts negatively on rehabilitation and reintegration.

\section{DIFFERENCES IN CRIMINAL RECORD REGIMES}

The merits or otherwise of criminal record disclosure tends to be demarcated by two competing imperatives - risk and rehabilitation. Those who argue that criminal records are relevant information that should be subject to disclosure do so on the basis that an information-holder (whether an employer or otherwise), can make an informed decision about whether a person is a suitable candidate in whom to place trust. Through this reasoning, a criminal record can tell us something about the character of

\footnotetext{
${ }^{3}$ Children's Commissioners are appointed in each of the countries comprising the UK: England, Wales, Northern Ireland and Scotland. Their roles are established in legislation and their primary purpose is to promote and protect the rights of children with particular reference to the United Nations Convention on the Rights of the Child. There are some differences in the remit and level of independence from government of the Children Commissioners across the UK jurisdictions, for instance some are involved directly in case work with individual children, while others are not. Equivalent roles are carried out by Children's Ombudsmen in European countries (see: Thomas 2011 for a comparative analysis).
} 
a person (ie their behavior in the past), but it also invites an assessment about their behavior in the future, that is to say an assessment of future risk. Such a view is contrary to the fact that we know that most offending escapes the attention of the criminal justice system and that people frequently commit serious offences without a prior record of offending. Furthermore, even where a record does exist its predictive validity decreases over time (Kurlychek et al 2007; Weaver 2018).

Some of the reasons for varying approaches to criminal records internationally can be explained by different socio-cultural contexts and the distinctions between common law and civil law systems (Jacobs and Larrauri 2012). They are also reflective of different approaches and attitudes towards privacy and rehabilitation (Kurtovic and Rovira 2017), and towards children and young people. Comparative analysis of the treatment of juvenile criminal records shows that many European countries treat records acquired as a child as confidential, meaning that they cannot be disclosed to third parties or in subsequent criminal proceedings when the child attains adulthood (Jehle et al 2008; Carr et al 2015). In Spain, for instance, the records of juveniles are held on a separate database and information provided on a criminal records certificate will not contain any information on records acquired as a juvenile (Carr et al 2015). Similarly, in France and Belgium, juvenile criminal records are not subject to disclosure for the purpose of certificates issued to employers (HerzogEvans 2011; Baert and Verhofstadt 2015). ${ }^{4}$ In some countries provisions also exist allowing for the expungement of juvenile criminal records. The following section will outline how the approach to criminal record retention and disclosure in England and Wales falls well short of international rights standards. It begins with an overview of the evolution of the criminal record regime, the various changes made over time, and the specific impacts on individuals of the treatment of records acquired as a juvenile.

\section{CRIMINAL RECORD REGIME IN ENGLAND AND WALES}

In 1972, the organisation Justice (the British Section of the International Commission of Jurists), NACRO (previously the National Association for the Care and

\footnotetext{
${ }^{4}$ It is worth noting, however, that while these general principles regarding the confidentiality of juvenile criminal records apply, juvenile criminal records can be disclosed in the context of immigration, asylum and residence applications (Carr et al 2015).
} 
Resettlement of Offenders) and the Howard League for Penal Reform jointly established an independent committee (The Gardiner Committee) to consider a procedure for limiting the disclosure of criminal records. At the time, the UK was the only member of the Council of Europe that did not have a mechanism in place for limiting disclosure requirements. The ensuing report of the committee - Living it Down - The Problem of Old Convictions (Justice 1972) proposed a system through which criminal convictions would be considered 'spent' after a period of time and this proposal ultimately led to the enactment of the Rehabilitation of Offenders Act (1974) $(R O A)$. As the title of this legislation suggests, the intention was to support the rehabilitation of persons who had been convicted of offences by limiting the circumstances under which they would be required to disclose their criminal record (Henley 2018). Under the ROA, a criminal conviction may become 'spent' after a certain period of time. ${ }^{5}$ A caution is considered spent immediately unless it was imposed with conditions attached. Within the legislation, a distinction is made between records of juvenile and adult offending, in that shorter time periods apply for a juvenile criminal record to be considered 'spent' than for offences committed as an adult. However, ever since its original enactment this legislation has been limited in the type of rehabilitation it affords (for example certain convictions can never be considered spent). Subsequent amendments to the ROA provided exemptions for certain professions ${ }^{6}$ and changes to the law over the years have shifted the balance further from the rehabilitation of the individual towards the protection of the public (Thomas 2008; Padfield 2011). ${ }^{7}$

The most significant of these changes was the introduction of a system for different levels of criminal record disclosures. The Police Act (1997) introduced a new regime of standard and enhanced disclosure for those wanting to work (or to volunteer to work) with children and vulnerable adults. The legislation provides for

\footnotetext{
${ }^{5}$ This legislation was originally enacted in England and Wales and Scotland. The Rehabilitation of Offenders (NI) Order, 1978 is the equivalent legislation for Northern Ireland.

${ }^{6}$ For example the Rehabilitation of Offenders Act 1974 (Exceptions) Order 1975 listed specific professions to which the legislation did not apply (S.I. 1975/1023) and the range of exceptions detailed in the Exceptions Order has expanded significantly over time (Mason 2010).

${ }^{7}$ The lengthy time periods before a conviction can be considered spent and the threshold at which this is set have been criticised (Padfield 2011). Provisions in the Legal Aid, Sentencing and Punishment of Offenders Act (2012) reduced the rehabilitation periods of the ROA and extended the provisions of the legislation to include prison sentences up to and including four years (see Henley 2018).
} 
three types of certificates to be issued: 1) Criminal Conviction Certificate, 2) Criminal Record Certificate and 3) Enhanced Criminal Record Certificate. The difference between the three types of certificates concerns the amount of information that is disclosed in each. In the first category, Criminal Conviction certificates (more commonly referred to as 'Basic' certificates) include information on current convictions and cautions (ie those that are not considered spent). In the second category, Criminal Record Certificates (more commonly referred to as 'Standard' certificates) contain all convictions and cautions, whether spent or otherwise, unless they have been subject to 'filtering'.

A system of 'filtering' was introduced by the government in 2013, which allows for certain old and minor convictions and cautions to be filtered (meaning that they do not appear on a person's criminal record certificate). A caution is filtered if it was given at least six years previously in the case of an adult and at least two years previously in the case of a person who was under 18 at the time of the conviction. A conviction can be filtered if it is a person's only conviction; it did not result in a custodial sentence; it occurred at least 11 years previously in the case of an adult, and at least five years previously in the case of a person who was under 18 at the time of conviction, and it was not for a 'listed offence'. Listed offences include a range of offending encompassing the most serious offences (e.g. murder, sexual assault and rape).

In the final category, Enhanced Criminal Record Certificates (ECRCs) contain all conviction and caution information spent or otherwise and also any additional information deemed relevant by the police. As Grace (2014) outlines, such information encompasses the following:

'allegations, records of arrest and/or charge and/or prosecution, statements by witnesses and (alleged) offenders themselves, cautions, convictions, records of penalty notices for disorder, sentencing reports, tax and/or benefit investigations, the placement of individuals on barring lists, and covert or overt police surveillance intelligences - as well as more peripheral 'intelligence' such as anti-social behaviour orders and reports of anti-social behaviour itself (despite the seemingly non-criminal nature of this behavior by its very definition).' (Grace 2014: 121) 
The Disclosure and Barring Service (DBS) conducts criminal record checks in England and Wales and issues a criminal record certificate which lists all 'relevant matters' recorded against the individual who is the subject of the application (Law Commission 2017). Equivalent bodies carry out these functions in Scotland (Disclosure Scotland) and in Northern Ireland (Access NI). On request for a criminal record check, the certificate is issued to the subject of the check who then provides it to their prospective employer or other relevant party (eg a professional body or a licensing authority). Criminal record checks are becoming increasingly routine and disclosures are made for a number of other purposes including in criminal trials (where a person's previous criminal history is considered relevant); in civil court proceedings, in university admissions; in insurance applications and for travel or resident visas (HoCJC 2017).

The system governing disclosure is complex and in some instances information is required on 'spent' convictions (e.g. in criminal proceedings for the purposes of sentencing or for adducing 'bad character', while in other instances information must only be disclosed on 'unspent' convictions (e.g. insurance applications). The picture is further complicated in the case of travel and residence visas, where the requirement to disclose spent and/or unspent convictions varies by country. The wide use of criminal records is illustrated by the fact that in 2015 the DBS processed 4.2 million applications in England and Wales alone (Law Commission 2017). ${ }^{8}$ The charity Unlock, which campaigns on behalf of people with convictions, estimates that over the past five years over 850,000 people have been affected by the disclosure of a youth criminal record (Stacey 2018).

\section{DIVERSION AND THE ILLUSION OF LESS CONSEQUENCE}

In England and Wales a separate youth justice system, distinct from the adult criminal justice system, operates for juvenile offenders. Children from age 10 (the minimum age of criminal responsibility) up to age 17 are dealt within this system. Traditionally

\footnotetext{
${ }^{8}$ The DBS describe their role as follows: The DBS helps employers make safer recruitment decisions and prevent unsuitable people from working with vulnerable groups, including children. Disclosure and Barring Service 'About Us'. Available at: https://www.gov.uk/government/organisations/disclosureand-barring-service/about. Accessed on 29 March 18.
} 
the purpose of separating the treatment of children from adult offenders has been in recognition of the fact that most young people grow out of crime and that involvement with the criminal justice system may lead to negative consequences. Debates around different approaches to youth justice have tended to oscillate between welfare and justice perspectives (Muncie and Goldson 2013). In the former, promoting the welfare of the child is seen as the primary consideration, but this has sometimes been used as justification for extensive intervention. A justice perspective is more typically associated with strategies of responsibilisation; that is, holding young people to account for their actions and ensuring that they are adequately punished for wrongdoing (Muncie 2008). In reality, however, youth justice systems tend to embody a range of contradictory rationales (McAlister and Carr 2014), and this becomes manifest in different approaches adopted towards young people who transgress the law and the nature of interventions undertaken.

The question of how interventionist the youth justice system should be is one that has been extensively debated. Many commentators, including children's rights advocates, favour less intervention through practices such as diversion from formal processing through the criminal justice system (Smith 2018). Insights from labeling theory (Lemert 1951; Becker 1963; Schur 1973) and empirical research exploring the effects of contact with the criminal justice system on children (McAra and McVie 2007; Petrosino et al 2010) have informed the view that diverting children away from the criminal justice system avoids potential negative effects such as association with offending peers and self-identification as an offender. However, the point at which children and young people are diverted is clearly important, as is the question of what they are diverted to? In England and Wales, community resolutions; cautions and conditional cautions (see Table 1 below) are characterised as diversionary or 'out-ofcourt' measures in that a young person is diverted from formal processing through the courts. However, this does not mean that they are diverted from contact with the youth justice system. In certain circumstances, young people subject to diversionary disposals still encounter a good deal of system contact, for example through requirements to engage with Youth Offending Services, aimed at reducing their risk of re-offending (Kelly and Armitage 2014; Smith 2014; Taylor 2016). Most importantly, such 'diversions' also lead to the acquisition of a criminal record.

Table 1 below provides an overview of diversionary or 'out-of-court' disposals currently available within the youth justice system in England and Wales, 
the intervention involved, criminal record implications and the police entitlement to gather bio-information (eg fingerprints and DNA). As will be evident, 'diversionary' disposals also result in the child acquiring a criminal record. If they do not meet the criteria for filtering, such disposals may remain on a person's criminal record ad infinitum, regardless of the age at which he or she acquired the record. Therefore, one of the main justifications for the use of diversionary disposals - to reduce the negative effects of system contact including the labeling of young people as offenders - is fundamentally undermined by the criminal record regime that currently operates in England and Wales. A further difficulty arises from treating such 'administrative' or 'regulatory' measures in the same manner as court convictions, in that the evidence is not tested to the same degree as it would be in court and the person makes an admission of guilt without recourse to an independent and impartial tribunal (Larrauri 2014a). Further still, research with young people shows that there is an inherent incentive to accede to diversionary measures precisely because they are perceived as being less consequential (Carr et al 2015).

Table 1: Diversionary 'out-of court' disposals for juveniles in England and Wales ${ }^{9}$

\begin{tabular}{|l|l|l|l|}
\hline Description & $\begin{array}{l}\text { Community Resolution } \\
\text { Tommunity resolution is } \\
\text { the term for the resolution } \\
\text { of a minor offence or anti- } \\
\text { social behaviour incident } \\
\text { through informal } \\
\text { agreement between the } \\
\text { parties involved. }\end{array}$ & $\begin{array}{l}\text { May be given for an } \\
\text { offence when the } \\
\text { young person admits } \\
\text { the offence and there } \\
\text { is sufficient evidence } \\
\text { for a realistic } \\
\text { prospect of } \\
\text { conviction, but it is } \\
\text { not in public interest } \\
\text { to prosecute. }\end{array}$ & $\begin{array}{l}\text { As per youth caution, but there is a } \\
\text { compulsory assessment and } \\
\text { intervention attached. The } \\
\text { conditions must have one or more } \\
\text { of the following objectives: } \\
\text { rehabilitation, reparation and/or } \\
\text { punishment. }\end{array}$ \\
\hline $\begin{array}{l}\text { Consent } \\
\text { required }\end{array}$ & $\begin{array}{l}\text { The young person's } \\
\text { agreement is required in } \\
\text { order to participate in and } \\
\text { accept a community } \\
\text { resolution. }\end{array}$ & $\begin{array}{l}\text { Children are required } \\
\text { to make an } \\
\text { admission of } \\
\text { offending in order to } \\
\text { receive a caution but } \\
\text { they are not required } \\
\text { to consent to a } \\
\text { caution, as is the } \\
\text { case for adults. }\end{array}$ & $\begin{array}{l}\text { The Youth Offending Team (YOT) } \\
\text { must assess the young person and } \\
\text { advise on appropriate conditions. The } \\
\text { young person must also agree to } \\
\text { accept the Youth Conditional Caution } \\
\text { and the conditions attached, as such } \\
\text { a child must consent to receiving a } \\
\text { conditional caution. If the young } \\
\text { person does not apply with the }\end{array}$ \\
\hline
\end{tabular}

\footnotetext{
${ }^{9}$ Source information: Youth Justice Board for England and Wales (2013) Youth Out-of-Court Disposals. Guide for Police and Youth Offending Services. London: YJB; Ministry of Justice (2013) Code of Practice for Youth Conditional Cautions. London: Home Office; Home Office (2017) CODE D Revised. Code of Practice for the identification of persons by Police Officers. London: Home Office.
} 


\begin{tabular}{|l|l|l|l|}
\hline $\begin{array}{l}\text { Criminal } \\
\text { record } \\
\text { implications }\end{array}$ & $\begin{array}{l}\text { Community resolutions } \\
\text { are an informal out-of- } \\
\text { court disposal and do not } \\
\text { form part of a criminal } \\
\text { record. However their } \\
\text { use is recorded and this } \\
\text { record may be } \\
\text { disclosed as part of an } \\
\text { enhanced criminal } \\
\text { record certificate. }\end{array}$ & $\begin{array}{l}\text { A caution is an admission of guilt, and as such a record of the } \\
\text { caution will be kept by the police and will appear on standard } \\
\text { and enhanced criminal record checks (unless subject to } \\
\text { filtering). }\end{array}$ \\
\hline $\begin{array}{l}\text { Fingerprints } \\
\text { and DNA }\end{array}$ & $\begin{array}{l}\text { Supporting fingerprints are required. Where fingerprints are not } \\
\text { taken at the time, the young person can be required to provide } \\
\text { fingerprints within two years of receiving the caution or } \\
\text { conditional caution. } \\
\text { DNA samples can be taken for certain offences and can be } \\
\text { retained for specified time periods. }\end{array}$ \\
\hline
\end{tabular}

The fact that a person may admit guilt does not mean that they fully understand the implications of doing so, particularly in relation to the longer-term consequences of criminal record disclosure. As outlined, the system relating to criminal record regimes in England and Wales is particularly complex and unwieldy and, by virtue of their maturity and level of understanding, children and young people are placed in a particularly invidious situation. Research conducted with children and young people to ascertain their understanding of the criminal record regime shows that many are under the misapprehension that when they reach adulthood their childhood record of offending is 'wiped clean' (Carr et al 2015). ${ }^{10}$ Furthermore, many children may admit guilt in the absence of sufficient legal advice (Kemp et al 2011). And even if children do receive sufficient legal advice, the changes to the system over time mean that the future consequences of diversionary disposals may be unforeseeable.

\section{LEGAL CHALLENGES TO THE CRIMINAL RECORD REGIME}

The wide scope of the criminal record regime in England and Wales has been challenged in a number of court appeals in recent years. Some of the concerns articulated in these cases include practices in relation to the retention of criminal record data and other information on the Police National Computer (PNC) and the disclosure of this data in criminal record checks. Significantly, a number of the appeal

\footnotetext{
${ }^{10}$ This research was commissioned by NIACRO and conducted in Northern Ireland where the criminal record regime is broadly similar to that of England and Wales (Mason 2011).
} 
cases relate to adults who had acquired records as juveniles and who were subsequently required to disclose these records many years later. In some cases, evidence was given that the individuals concerned erroneously believed that their records were considered 'spent' or deleted. However, policy changes in respect of the retention of data and the requirements for the police to disclose this had changed in the intervening years, meaning that for some individuals, childhood transgressions would be subject to disclosure for the rest their life. In one legal case, the judge likened this to an albatross around one's neck, which could never be shaken off. ${ }^{11}$ In one of the most significant legal cases $-R$ (T and others) $v$ Chief Constable of Greater Manchester ${ }^{12}$ - the applicants argued that the blanket disclosure of all convictions and cautions was contrary to Article 8 (respect for family and private life) of the European Convention on Human Rights (ECHR). In this case one of the appellants, 'T', who was aged 21 at the time of the legal action, challenged the disclosure of warnings ${ }^{13}$ he had received as an 11-year-old for the theft of two bicycles, when he applied for a place on a sports studies course at university. These warnings were disclosed in an Enhanced Criminal Record Check required because the course involved work with children. ${ }^{14}$ The court ultimately held that blanket disclosures of all convictions and cautions were disproportionate to the legitimate aim of public protection and that the relevant legislation (ROA Order and the Police Act 1997) was incompatible with Article 8 and therefore ultra vires.

The government appealed this case and in the subsequent Supreme Court judgment $-[R$ (on the application of $T$ and another) $v$ Secretary of State for the Home Department and another [2014 UKSC 35] the court held that as cautions take place in private they are part of a person's private life from the outset. Drawing on the line of reasoning set out in $R(L) v$ Commissioner of Police of the Metropolis [2009] UKSC 3,

\footnotetext{
${ }^{11}$ Lord Wilson at Para 48 in $R$ (on the application of $T$ and another) $v$ Secretary of State for the Home Department and another. [2014] UKSC 35. The albatross in Coleridge's Rime of the Ancient Mariner is fastened to the neck of the sailor after he has killed it. He prays and the albatross falls from his neck and he is eventually rescued from sea, but he is forced to retell the story for the rest of his life.

12 [2013] EWCA Civ. 25

${ }^{13}$ For offenders under the age of 18, reprimands and warnings were formerly available instead of cautions (section 65 Crime and Disorder Act, 1998), and the provisions of the ROA relating to cautions apply equally to warnings and reprimands. The provisions of the Crime and Disorder Act 1998 have since been amended and 'cautions' and 'conditional cautions' replace reprimands and warnings.

${ }^{14}$ The other two appellants in this case were JB who received a caution for the theft of false nails from a store over a decade earlier and AW who aged 16 was charged with offences of manslaughter and robbery. She was 26 at the time of the application and wished to join the army. Both T and JB were granted leave to appeal but AW's application was rejected.
} 
which concerned the disclosure of a conviction, the Court further confirmed the view that with the passage of time criminal records should become part of a person's private life. On the question of the disclosure of information in ECRCs, the court agreed that such disclosure significantly jeopardised the respondents' entry into education or employment:

'In the present appeals it is true that, in the end, $\mathrm{T}$ was allowed to enroll on the sports studies courts and it is possible, albeit unlikely, that, not withstanding the refusal of the provider of the training course to put her forward for work in the care sector, JB could have secured it by direct application. But the point is that, in both cases, the disclosure in the ECRCs of the cautions issued to them significantly jeopardised entry into their chosen field of endeavour.' [Lord Wilson, [R (on the application of $\mathrm{T}$ and another) v Secretary of State for the Home Department and another 2014 UKSC 35 Para 20].

The Supreme Court noted that the respondents' criminal records, once disclosed, interfered with their Article 8 rights. Drawing on a European Court of Human Rights judgment in relation to the retention of DNA samples and fingerprints of persons suspected but never convicted of offences, ${ }^{15}$ which held that such blanket retention was in contravention of Article 8 rights, the Court considered that compared to the 'highly personal and sensitive nature' of DNA material, criminal record information was 'not in that league' but that retention of the information could nevertheless be open to further challenge. The Supreme Court allowed the appeal in parts and found that despite the introduction of a 'filtering system', the current system still fails to adequately determine the relevance of data for the purpose disclosed, the time elapsed since the commission of the offence, the nature of the offence and the disposal (Law Commission 2017). In other words, the wide breadth of criminal record disclosure does not adequately account for relevance, ie whether the matter being disclosed is pertinent to the situation in question. So for instance, one can appreciate that a record of a driving offence is relevant to a position where a person is required to drive as part of their job, but it would not be if they were in an administrative role. Further still the current system does not adequately account the passage of time and it

\footnotetext{
${ }^{15} S v$ United Kingdom (2009) 48 EHRR 1169
} 
does not reflect relevant contextual information such as the circumstances surrounding the offence.

While the filtering system was introduced following the initial legal challenge in $T$ and Others ${ }^{16}$ and was intended to limit disclosures of 'old and minor' offences, its scope has been limited by the number of preconditions that apply. The list of "nonfilterable' offences is unwieldy and complex. Problematically, the range of nonfilterable offences draws on various pieces of legislation so that it is unclear what exactly is included in the 'listed' offences, rendering it unintelligible to those without relevant expertise or resources. Further still, there is a lack of clarity about jurisdictional equivalence, meaning that offences that may be filterable or nonfilterable in one UK jurisdiction (ie England and Wales, or Scotland and Northern Ireland) may not be in another. The restriction that only one conviction or caution meeting the criteria outlined above can ever be filtered is also problematic, and particularly so when multiple offences are committed in the course of one incident.

In a recent review, the Law Commission noted the complexity of a criminal records disclosure system which has been overlaid with different reforms:

'... makes it hard to understand and inaccessible to users... These difficulties arises both from the fact that a number of different pieces of legislation must be referred to in order to identify offences that are non-filterable, and that an up to date copy of the relevant legislation is currently only accessible from legal databases available on subscription.' (Law Commission, 2017:9)

Aside from general concerns regarding intelligibility, it also noted that noted that 'the system might be regarded as disproportionately harsh in its effect on young offenders', in that a sufficient distinction is not made between criminal records acquired as a juvenile and those acquired in adulthood (Law Commission 2017:14). The concerns regarding the disproportionate effects of the regime on children and young people have been echoed in a review of the youth justice system (Taylor 2016) and a report from the House of Commons Justice Committee (HoJC 2017). All of these bodies have called for rationalisation and reform.

\section{CONCLUSION}

${ }^{16}$ [2013] EWCA Civ. 25 
The criminal record regime in England and Wales does not adequately recognise the possibility for rehabilitation. Legislation introduced over forty years, aimed at the 'Rehabilitation of Offenders' which provided for certain convictions to be considered 'spent' after a specific time period has been eroded by further laws and regulations geared towards public protection. The emphasis on public protection is predicated on a belief that knowing about a person's past record of offending can lead to informed decisions about what risks they may pose. This is in spite of evidence that shows the limited predictive validity of a criminal record over time.

Although there is separate justice system for children, the regime for criminal record disclosure does not adequately differentiate between children and adults. The range of circumstances in which people are required to disclose criminal records has broadened and in some situations old records of juvenile offending are routinely disclosed. This has meant that a criminal record hangs like an albatross around a person's neck, requiring a constant retelling of past misdeeds. The situation in England and Wales is in clear contravention of children's rights standards, and it stands in contrast to other countries where records of juvenile offending are sealed. Reforming the current system to limit criminal record disclosure would be a positive step in reducing the impacts of system contact, long after that contact has ceased.

Acknowledgement

I would like to thank Andy Henley for his helpful comments on a draft of this chapter.

\section{REFERENCES}

Baert, S \& Verhofstadt, E (2013) 'Labour market discrimination against juvenile delinquents: Evidence from a field experiment.' Working Paper 2013/852. Available from: http://wps-feb.ugent.be/Papers/wp 13 852.pdf Becker, HS (1963) Outsiders (New York, Free Press). Carr, N, Dwyer, C \& Larrauri, E (2015) Young People, Criminal Records and Employment Barriers (Belfast: NIACRO). Committee on the Rights of the Child (2016) Concluding Observations on the Fifth Periodic Report of the United Kingdom of Great Britain and Northern Ireland. Council of Europe (2010) Guidelines of the Committee of Ministers of the Council of Europe on Child Friendly Justice (Adopted by the Committee of Minister on 17 
November 2010 at the $1098^{\text {th }}$ meeting of the Ministers' Deputies), Strasbourg, Council of Europe.

House of Commons Justice Committee (HoCJC) (2017) Disclosure of Youth Criminal Records. First Report of Session 2017-19 (London, House of Commons).

Gardiner Committee (1972) Living it Down - The Problem of Old Convictions. A Report of the Gardiner Committee (London, Stevens \& Sons)

Goldson, B. \& Muncie, J. (2012) 'Towards a global 'child friendly' juvenile justice.'

International Journal of Law, Crime and Justice, 40, 47-64.

Grace, J (2014) 'Old Convictions Never Die, They Just Fade Away: The Permanency of Convictions and Cautions for Criminal Offences in the UK' The Journal of Criminal Law, 78, 121-35.

Henley, A (2018) 'Mind the Gap: Sentencing, Rehabilitation and Civic Purgatory' Probation Journal, DOI: 10.1177/0264550518776773

Herzog-Evans, M (2011) 'Judicial Rehabilitation in France: Helping with the Desisting Process and Acknowledging Achieved Desistance' European Journal of Probation, 3,1: 4-19.

Jacobs, JB \& Larrauri, E (2012) 'Are criminal convictions a public matter? The USA and Spain' Punishment \& Society January 2012 14, 1: 3-28.

Jacobs, JB (2014) 'Juvenile Criminal Record Confidentiality' in FE Zimring and DS Tanenhaus (eds) Choosing the Future for American Juvenile Justice (New York, New York University Press), 149-68.

Jehle, J, Lewis, C \& Sobota, P (2008) 'Dealing with Juvenile Offenders in the Criminal Justice System' European Journal of Criminal Policy Research, 14, 2-3, 237-47.

Justice (1972) Living It Down: The Problem of Old Convictions. London: JUSTICE. Kelly, L \& Armitage, V (2014) 'Diverse Diversions: Youth Justice Reform, Localized Practices, and a 'New Interventionist Diversion'?' Youth Justice, 15, 2: 117-33.

Kemp, V, Pleasance, P \& Palmer, NJ (2011) 'Children, young people and requests for police station legal advice: 25 years on from PACE.' Youth Justice, 11, 1: 28-46.

Kilkelly, U (2008) 'Youth Justice and Children's Rights: Measuring Compliance with International Standards' Youth Justice, 8, 3, 187-92.

Kurlychek, MC; Brame, R \& Bushway, SD (2007) 'Enduring Risk? Old Criminal Records and Predictions of Future Criminal Involvement.' Crime and Delinquency, 53,1, 64-83.

Kurtovic, E \& Rovira, M (2017) 'Contrast between Spain and Netherlands in the hidden obstacles to re-entry in the labour market due to a criminal record' European Journal of Criminology, 14,5, 505-21.

Larrauri, E (2014a) 'Are Police Records Criminal Records? Disclosure of Criminal Information and the Presumption of Innocence.' European Journal of Crime,

Criminal Law and Criminal Justice, 22, 4, 377-95.

--- (2014c) 'Legal protections against criminal background checks in Europe.'

Punishment and Society, 16, 1, 50-73

Law Reform Commission (2017) Criminal Records Disclosure: Non-Filterable Offences (Law Com. No. 371). (London, Stationery Office).

Lemert, E (1951) Social Pathology (New York, McGraw-Hill).

McAlister, S \& Carr, N (2014) 'Experiences of youth justice: Youth justice discourses and their multiple effects' Youth Justice, 14(3), 241-54.

McAra, L \& McVie, S (2007) 'Youth Justice? The Impact of System Contact on Patterns of Desistance from Offending.' European Journal of Criminology, 4,3, 315 34. 
Mason, S (2010) A Balanced Approach. Independent Review by Sunita Mason. Safeguarding the Public Through the Fair and Proportionate Use of Accurate Criminal Record Information. Available at:

http://webarchive.nationalarchives.gov.uk/20100418065544/http:/police.homeoffice.g ov.uk/publications/about-us/ind-review-crim/a-balanced-approach-

12835.pdf? view $=$ Binary (Accessed on: 04 May18)

Mason, S (2011) A Managed Approach. A Review of the Criminal Records Regime in Northern Ireland. Part 1. (Belfast, Department of Justice).

Muncie, J (2008) 'The 'Punitive Turn' in Juvenile Justice: Cultures of Control and Rights Compliance in Western Europe and the USA' Youth Justice, 8, 2, 107-21. Muncie, J \& Goldson, B (2013) 'Youth Justice: In a Child's Best Interests?' in R Sparks and J Simon (eds) The Sage Handbook of Punishment and Society (London, Sage), 341-55.

Naylor, B (2011) 'Criminal Records and Rehabilitation in Australia' European Journal of Probation, 3, 1, 79-96.

Padfield, N (2011) 'Judicial Rehabilitation? A View from England' European Journal of Probation, 3, 1, 36-49.

Petrosino, A, Turpin-Petrosino, C \& Guckenburg, S (2010) 'Formal System Processing of Juveniles: Effects on Delinquency' Campbell Systematic Review, 2010,1 .

Schur, E (1973) Radical Nonintervention: Rethinking the Delinquency Problem. (Englewood Cliffs, New Jersey, Prentice-Hall).

Smith, R (2014) 'Re-inventing Diversion' Youth Justice, 14, 2, 109-21.

--- (2018) Diversion in Youth Justice. What Can we Learn from Historical and Contemporary Practices (London, Routledge).

Stacey, C (2018) A Life Sentence for Young People. A Report into the Impact of Criminal Records Acquired in Childhood and Early Adulthood (Kent, Unlock). Taylor, C (2016) Review of the Youth Justice System in England and Wales (London, Ministry of Justice).

Thomas, N. (2011) 'The role and impact of independent children's rights institutions in the UK and Europe.' Journal of Social Welfare and Family Law, 33,3, 279-288. United Kingdom Children's Commissioners (2015) Report of the UK Children's Commissioners. UN Committee on the Rights of the Child Examination of the Fifth Periodic Report of the United Kingdom of Great Britain and Northern Ireland.

Available at: https://www.childcomwales.org.uk/wp-content/uploads/2016/04/Reportof-the-UK-CCs-UNCRC-Examination-of-the-Fifth-Periodic-Report.pdf United Nations Committee on the Rights of the Child (2007) General Comment No. 10: Children's Rights in Juvenile Justice. Forty-fourth session, 15 January - 2 February. Geneva: Office of the High Commissioner for Human Rights. Weaver, B (2018) 'Time for Policy Redemption? A Review of the Evidence on Disclosure of Criminal Records' (Glasgow, SCCJR). Youth Justice Board for England and Wales (2013) Youth Out-of-Court Disposals. Guide for Police and Youth Offending Services (London, YJB).

\section{LIST OF CASES}

\section{European Court of Human Rights}

Sv United Kingdom (2009) 48 EHRR 1169 


\section{Domestic cases}

$R$ (on the application of $T$ and another) $v$. Secretary of State for the Home Department and another [2014 UKSC 35]

$R$ (T and others) v Chief Constable of Greater Manchester. [2013] EWCA Civ. 25

$R(L) v$ Commissioner of Police of the Metropolis [2009] UKSC 3 